\title{
Beliefs and trade union support for trade liberalisation in the US and the UK: the AFL-CIO
} and the TUC compared

\author{
Author: Juan Díez Medrano \\ Department of Social Sciences, Universidad Carlos III de Madrid \\ E-mail: juan.diez@uc3m.es \\ Journal of International Relations and Development. DOI: doi.org/10.1057/s41268-017-0084-2.
}

\begin{abstract}
This article applies an interpretive approach to behaviour to explain why the United States' American Federation of Labor - Congress of Industrial Organizations (AFL-CIO) has opposed free trade agreements whereas the British Trade Union Congress (TUC) has endorsed them and why the AFLCIO shifted its position on trade liberalisation around 1970. The AFL-CIO has opposed FTAs because it views past costs of trade liberalisation as excessive and believes that FTAs do not protect workers enough against surges in imports. The British TUC has accepted FTAs and the enlargement of the EU because it sees no economic alternative to open markets. On a substantive level, the article describes how the US and the British trade union confederations have approached trade liberalisation and FTAs. On an analytical level, the article emphasises the autonomy of individual and group beliefs with respect to structures and with respect to dominant ideas and therefore the need to examine these beliefs when explaining behaviour.
\end{abstract}

Keywords: constructivism; European Union; free trade agreements; United Kingdom; United States; trade unions. 


\section{Introduction}

In the last thirty years, free trade agreements (FTAs) have replaced multilateral trade negotiations as the main vehicle to trade liberalisation (Mansfield and Milner 1999; Duina 2006). This article examines how, in the context of de-industrialisation and firm relocation to less developed countries, trade union confederations (TuCs) in the US and the UK approached these trade agreements in the period from 1985 to 2012 . TuCs are the main organisations in the US and the British trade union movement, with trade policy as one of their specialised functions relative to what most member trade unions do (Holloway 1979). TuCs are regularly consulted before and during trade negotiations and they participate in public debate. Although their power to shape trade agreements is limited, they are far from irrelevant. Their lobbying and mobilisation efforts, for instance, partly explain the inclusion of a labour chapter in FTAs (i.e. NAFTA). TuCs have also won major battles, for instance in 1997 and 1998 when the US Congress gave in to pressure and denied Fast-Track Authority to the President (Shoch 2000); or when German and Austrian trade unions achieved transition periods for the movement of workers in the 2004 EU enlargement treaty (Hofhansel 2001). This article does not address, however, the TuCs' power to shape trade policy. Instead, it focuses on their support for or opposition to trade liberalisation.

The comparison between the US and the British TuCs highlights a puzzling contrast: the American Federation of Labor - Congress of Industrial Organizations (AFL-CIO) has rejected all but one of the FTAs (Jordan), whereas the British Trade Union Congress (TUC), along with other trade union confederations in the EU, has endorsed all FTAs but one (Colombia). An interpretive approach to explanation that highlights the reasons and justifications that the TuCs' representative officials provide shows that the AFL-CIO has opposed FTAs because it views past costs of trade liberalisation as excessive and believes that FTAs do not protect workers enough against the surges in imports. The AFL-CIO believes that foreign imports and trade deficits are bad for American workers. Meanwhile, the British TUC, as sensitive to the risks of trade liberalisation as the AFL-CIO and sharing in the US 
TuCs' negative perception of the effect of imports and trade deficits, has accepted FTAs and the enlargement of the EU because it believes that there is no economic alternative to open markets.

On a substantive level, the article describes how the US and the British TuCs have approached trade liberalisation and FTAs. On an analytical level, the article emphasises the autonomy of individual and group beliefs with respect to structures and with respect to dominant ideas and, therefore, the need to examine these beliefs when explaining behaviour (e.g. Abdelal et al. 2010). By emphasising the role of beliefs - whose truth content is for our purposes irrelevant - the article reminds us of the interpretative nature of behaviour. It primarily engages traditional approaches of International Political Economy (IPE) that assume perfectly informed and rational actors and a quasimechanical impact of economic structures on individual and group behaviour along the predictions of stylised formal models that are themselves disputed both within and from without the disciplines where they were first formulated. In addition, it sensitises to the autonomy of weak agents' beliefs (i.e. TuCs) relative to the dominant beliefs that inform contemporary trade policy. The recurrence of the same arguments made in favour or against FTAs over more than three decades against the background of major changes in the economy, in politics, and in the TuCs' sectorial internal composition, leadership, and distribution of power, the complete absence of documents hinting at dissent with respect to FTAs within the TuCs and the controverted status of some of the claims they make are the evidence that I use to establish the relevance of beliefs in the explanation of the TuCs' position on FTAs.

Primary and secondary sources pertaining to claims about trade policy made by the US and the British TuCs are the main empirical materials for this study. This type of data is appropriate for projects like this one, which cover long periods. I combine standard historico-sociological comparative methods with systematic analysis of two sets of documents: first, the AFL-CIO's official statements concerning each of the FTAs signed by the US government between 1985 and 2012, and second, verbatim transcripts of the TUC's annual congress for the period from 1997 to 2012 . For all AFL-CIO statements and all text blocs related to trade and FTAs in the TUC's transcripts, I coded all 
phrases related to 1) descriptions and 2) evaluations of 3) free trade in general and 4) specific FTAs or the EU enlargement.

My historico-sociological comparative analysis and interpretation are informed by a thorough examination of many additional sources: secondary literature, information provided by officials from the AFL-CIO and the TUC, and hundreds of documents concerning trade, working conditions, deindustrialisation, and related topics. The information from the TUC's officials comes from a different comparative project that deals with NAFTA and the EU enlargement: in 2008, as part of the project, I corresponded with nineteen representatives of the AFL-CIO and its member unions and with twentythree representatives of the TUC and its member unions. ${ }^{1}$ The primary documentation includes the US Senate and the House of Representatives Hearings on trade policy, the AFL-CIO's Executive Council minutes, transcripts from the TUC's annual conference, and newspaper articles from the New York Times, the Guardian, and FT. Unfortunately, the yield of this extensive search has been very poor. With few short-term exceptions, trade policy has been marginal to the US and the British TuCs' internal discussion. Also, although the press regularly informs on issues related to foreign trade and foreign policy, trade unions very rarely feature in national newspaper articles. Because of this I do not analyse the newspaper information in a more systematic way in this article, but use it instead as a consistency check for the conclusions drawn from the more systematic analysis of the restricted set of documents described above.

The rest of the article is structured as follows. I first examine and discard six structural explanations of the contrast between the AFL-CIO and the TUC. Then, I outline the interpretive analytical framework that guides this inquiry. The empirical part of the article begins with a systematic analysis of how the US and the British TuCs have discussed free trade and related agreements. I then focus on and interpret the AFL-CIO's espousing of a protectionist agenda in the late 1960s. A sequential examination of the US/UK contrast and of the AFL-CIO's shift helps us to convey the usefulness of the interpretive approach better and, at the same time, it helps us to understand the US/UK contrast better by putting the AFL-CIO's views in a historical perspective. 


\section{Competing explanations}

Three strands of research contribute to our understanding of support for free trade and, by extension, support for FTAs. Work in economics claims that countries that depend more on foreign trade benefit more from trade liberalisation than the less dependent ones (Alesina et al. 2005). For many years, international trade theory has also built on the idea that relative factor abundance across countries explains who benefits and who suffers from free trade (e.g. Stolper and Samuelson 1941; Ohlin 1967; Leamer 1995). Political economy has then drawn from this theory to predict who supports and who opposes trade liberalisation (Mayda and Rodrik 2005; O'Rourke and Sinnott 2002; Hiscox 2002; Midford 1993; Rogowski 1987). Finally, sociology and political economy report positive correlations between trade dependence, welfare state generosity, and support to trade liberalisation (e.g. Hwang and Lee 2014; Brady et al. 2007; Burgoon 2001; Katzenstein 1985; Cameron 1978). None of the factors above account for the contrast between the AFL-CIO and the TUC.

\section{Factor endowment}

The US and the UK resemble one another in that their semi-skilled workers can no longer compete with those from less developed countries. In both countries, comparative advantage benefits workers in high value-added occupations in the industrial and service sectors (e.g. Jensen and Kletzer 2005). Since most of the FTAs signed in recent decades by the US and the UK (i.e. the EU) have been with emerging economies or less developed countries, one would have expected the AFL-CIO and the TUC to be equally defensive on trade matters. In particular, from a purely economic perspective, the TUC, like many other EU TuCs, should have been very reluctant to agree to the EU enlargement to Central and Eastern Europe: in contrast to all the FTAs signed by the UK and the US, it not only eliminated barriers to the movement of goods, capital, and services, but also barriers to the movement of workers. 


\section{Labour protection systems and support to FTAs}

The literature has identified connections between the generosity of welfare states, support for trade liberalisation by the working class, and the significance of foreign trade for a country's economy. The EU has always boasted a more advanced system of labour protection than the US, which suggests that this contrast may play a role in explaining why the AFL-CIO has opposed FTAs whereas the European TuCs have endorsed them. A specific comparison between the US and the UK, however, calls this inference into question.

British workers are more widely covered by collective agreements than the US workers. They also enjoy universal health coverage whereas the US workers do not. Finally, British workers have been protected by the EU's Social Charter against the worst excesses of anti-labour reform (Mullen 2005). ${ }^{2}$ If one focuses, however, on unemployment and pension benefits, the two variables that have concerned the AFL-CIO most in the last forty-five years, indicators of welfare state generosity reveal that the US system has been as generous as the British one (Scruggs 2007; Scruggs et al. 2014; see also Freeman 2007). The values of Scruggs' unemployment generosity index calculated for 1971 in the UK and the US are 5.6 and 8.1 respectively; the corresponding values for 1991 are 8.4 and 9.8 respectively and those for 2010 are 8.3 and 10.7 respectively. This contrast in support to unemployed workers is only partially balanced through more investment in active labour market programmes in the UK than in the US. Scruggs' pension generosity index reveals a great deal of similarity: the UK values for 1971, 1991, and 2010 are 9.5, 10.3, and 11.3, whereas the US values are 7.9, 11.2, and 11.0. From a longitudinal perspective, the stability of support to FTAs in Britain in spite of steady declining collective agreement coverage rates and welfare state retrenchment also runs counter to the labour protection argument (Freeman 1995). In sum, the British system of worker protection is somewhat more generous than the US's, but the difference is not so large as to justify viewing this as the explanation for the contrast between the AFL-CIO and TUC in support to FTAs.

\section{Trade dependence}


A structural approach would immediately notice that the theoretically relevant variable that best correlates with the AFL-CIO/TUC contrast is trade dependence, which, as I show below, features prominently in the AFL-CIO's and TUC's official discourses. Examination of the ratio of the sum of the value of imports and exports over the GDP shows that British dependence on foreign trade tripled, even quadrupled the US's until the late 1980s and still doubles it nowadays. In the last thirty years, the share of trade over the GDP has increased in the two countries.

Trade dependence as such, however, did not cause the TUC to support FTAs, just as it did not push the AFL-CIO to oppose them. Trade dependence is not a necessary cause of support for trade liberalisation nor an explanation for the contrast between the British and the US TuCs, for despite the low dependence of the US on trade, the AFL-CIO supported trade liberalisation until the late 1960s. The analysis of the AFL-CIO documents below reveals that the AFL-CIO has closely monitored trade balance over the years and that what triggered its change of attitude toward trade liberalisation were the US trade deficits. Before addressing this issue, however, the following sub-sections examine alternative explanations that do not figure prominently in the political economy of trade literature but that could play a role in the explanation of the contrast between the AFL-CIO and the TUC.

\section{Institutions and the negotiation of FTA}

Pressure to compete in world markets and the difficulty of negotiating multilateral trade agreements underlie recent FTAs (see Table 1) signed by the US and the EU. Most of these have been with the less developed world. The AFL-CIO has been uncompromising and demanded protection, a strong Trade Assistance program, labour chapters in FTAs, minimum labour standards, the exclusion of public procurement, and strict monitoring, dispute settlement, and sanctioning procedures regarding labour issues. Meanwhile, more passive than the AFL-CIO, the TUC has endorsed FTAs, supported the EU enlargement to Central and Eastern Europe, and consistently advocated the bundling of trade agreements with minimum social standards (Burgoon and Jacoby 2011). 


\section{[Table 1]}

In both the US and the EU, TuCs are consulted at all levels during international trade negotiations. In the US, trade policy is the prerogative of the Congress, although it can grant Fast-Track Authority to the Executive Branch. In the EU, international trade policy is a competence of its supranational institutions. Member states, however, still frame the objective of the negotiations, authorise their start, are active in the negotiations (i.e. Article 133 Committee), and have the final say (together with the European Parliament) on the approval of FTAs. Despite these institutional contrasts, which make the EU trade negotiations a two-level game (see Ehrlich 2007), the US and the EU TuCs have had a similar impact on trade policy. There is, thus, no reason why Europeans should be less motivated than Americans and, indeed, both have voiced their views when they felt they had to (see Introduction). Therefore, the trade policy-making process does not account for the observed contrast between the AFL-CIO and the TUC.

\section{FTA's labour content}

The literature on FTAs and documentary evidence show that, except for the socially ambitious EU enlargement treaties, the social content of the FTAs signed by the US and the EU is very similar and has converged. Since the adoption of the Global Europe strategy in 2006, FTAs signed by the EU no longer subject labour rights violations to the same dispute settlement and sanctioning procedures as

other treaty violations (Hillary 2011; Horng 2003). ${ }^{3}$ European TuCs have been critical but have refrained from opposing subsequent FTAs. Meanwhile, the US's New Trade Policy for America (2007) requires signatories of FTAs to enforce their own labour laws and to implement core ILO conventions. It also makes compliance with labour provisions in FTAs subject to the same dispute settlement and sanctioning mechanisms as other chapters in the FTAs (Rogowsky and Chyn 2007; Kirschner 2011). One would have expected the AFL-CIO to welcome the New Trade Policy for America since the only FTA that it had endorsed till then was the one with Jordan, precisely on the 
grounds that it was drafted in these more labour-friendly terms. The AFL-CIO has been inflexible, however, and rejected all the FTAs drafted in the new language. In sum, similarity and convergence in the social content of the FTAs that the US and the EU have signed suggest that one should look elsewhere for an explanation for why the AFL-CIO has opposed them while the TUC has endorsed them.

\section{Internal composition of the AFL-CIO and the TUC}

The British and the US labour movements are much weaker now than they once were. In 2005, union density stood at $29 \%$ in the UK and $11 \%$ in the US, down from a peak of $52 \%$ in the UK (1981) and of $31 \%$ in the US (1960). More relevant to the explanation of the AFL-CIO's and the TUC's approach to FTAs, however, is the TuCs' internal membership structure. One could speculate that the manufacturing sector, the one most challenged by trade liberalisation, is better represented in the membership of the AFL-CIO than in that of the TUC and that, therefore, its views on FTAs have more weight in the former than in the latter. The empirical evidence does not support this hypothesis.

In the post-WWII era, the added value of manufacturing production relative to the GDP declined in the UK and the US from close to $40 \%$ to less than $20 \%$, so that half-way into the first decade of the new millenium, when most of the FTAs were signed, it stood at $12 \%$ in the UK and $14 \%$ in the US. This similarity in the evolution of the manufacturing sector in the UK and the US has been mirrored in the membership structure of the British and US TuCs. Between 1995 and 2000, the weight of the manufacturing sector in the unionised population changed from $18 \%$ to $15 \%$ in the UK and from $22 \%$ to $19 \%$ in the US. This similarity in membership structure makes an explanation of the US/UK contrast based on the different power of unions in the manufacturing sector unlikely. Given the concomitant increase in the share represented by members of unions less affected by globalisation, in the service and public sectors, one would have actually expected both the AFL-CIO and the TUC to become more favorable to FTAs. 
The sections above have noted some contrasts that may be causally related to the AFL-CIO's and TUC's different approaches to trade liberalisation. None of them, however, accounts for the contrast. To fully understand it, we must move from structures to meaning.

\section{A meaningful approach to the trade union support to FTAs}

This article situates itself in the social constructivist tradition in International Relations (IR) and International Political Economy (IPE). Constructionism emphasises the co-constitution of structures and agents, the emergent and inter-subjective character of interests, and how ideas (e.g. worldviews, cognitive scripts, beliefs, theories), identity, norms, habits, and values, individual or embedded in institutions, inform behaviour (e.g. Abdelal et al. 2010; Hopf 2010; Jackson and Nexon 2009; Bieler and Morton 2008; Finnemore and Sikkink 2001; Checkel 1998). Despite Rodrik's (2014) claim that ideas have been strangely absent from IPE, research that privileges ideas has in fact inspired much of the empirical literature in IR and IPE for almost two decades (e.g. Seabrooke and Wigan 2016; Braun 2014; Watson 2014; Blyth 2002, 2013; Abdelal 2009; Widmaier 2004; McNamara 1999). Max Weber's ideas loom large in this tradition. This article diverges from previous work in that it shifts from a focus on the study of the policy and governability paradigms (Braun 2014) that inform the economic and political elites' behaviour to a focus on how ideas also inform the behaviour of other participants in political debates over economic policy.

In The Protestant Ethic and the Spirit of Capitalism, Max Weber (1905/2010) stresses that not an external structure, the Protestant doctrine, but the specific way in which some protestant denominations interpreted this doctrine, propitiated the emergence of those behavioural traits that he groups under the label the 'spirit of capitalism'. In this 'spirit', I focus on how the British and the US TuCs have interpreted FTAs and the FTAs' impact on the welfare of workers and on how these interpretations have informed the TuCs' decision to reject or endorse FTAs. The TuCs' ideas matter, first of all, because individuals and, by extension, organisations, are not automata, at least when it comes to non-routine courses of action. Their behaviour is thus preceded by reflection on the best 
course of action. The ideas that social agents mobilise also matter because individuals are not fully informed, fully capable of processing their environment (March and Simon 1958) as neoclassical economics and traditional IR and IPE assume. Bounded rationality means that one cannot predict behaviour by simply examining structural conditions. Finally, ideas matter because gaps, ambiguities, and contradictions in the information available to agents leave too much uncertainty as to how to pursue one's interest. The study of international trade theory illustrates this problem perfectly.

Embedded within the neoclassical economics mainframe, international trade theory builds on the Heckscher-Olin approach, which assumes factor mobility across industries, and the Ricardo-Viner approach, which does not make this assumption. The theory provides insights as to whether or not, and if yes, under what conditions, free trade is preferable to protection and as to who wins and who loses from trade liberalisation. It cannot determine, however, the actual benefits and losses of different policy options for different groups, which is what political actors want to know before they take a stand on actual trade policy proposals. Partly because of this, and in keeping with the macroeconomics tradition (Braun 2014), international trade theory has inspired econometric models that evaluate how well the theory fits the world and, at the same time, help estimate the actual impact (e.g. on welfare, wages, earnings, income risk) that different levels of trade liberalisation and different levels of imports and exports have on the economy and on various groups in the population. As usual, however, the translation from the theoretical models to the econometric ones has not been straightforward. Theoretical ambiguity and data and statistical technology constraints mean that different econometric solutions are possible depending on the researchers' approach to the core general equilibrium paradigm, on their assumptions about the market, the number of relevant production factors, mobility across sectors in the economy, and other aspects of trade and the economy, on available indicators to measure key concepts (on the socially constructed character of data and indicators, see Coyle 2014; Gitelman 2013), and on different statistical methods. Thus, although the econometric models converge toward certain answers, there is enough room for discretion when assessing the models and too much uncertainty about how to interpret the results. As recently as 2008, Paul Krugman (2008: 
135) admitted the following: 'How can the actual effect of rising trade on wages be quantified? The answer, given the current state of the data, is that it can't $[\ldots]$. Putting numbers on these effects, however, will require a much better understanding of the increasingly fine-grained nature of international specialization of trade'.

The high degree of uncertainty in estimates of the impact of international trade discussed above diminishes the rhetorical power of the dominant discourse on the benefits of free trade (on power and ideas, see Carstensen and Schmidt 2016; Widmaier 2016) and opens the door for factors other than cold rational theoretical and empirical analysis (e.g. theoretical, methodological, social, psychological) to intervene in shaping the beliefs that TuCs develop as to the impact of trade liberalisation on the workers' well-being. For all the reasons above, an explanation of the TuCs' approach to FTAs must take the political actors' beliefs into account.

As I show below, the US and the British TuC have stayed within the neoclassical tradition and approached trade liberalisation by looking at variables - trade dependence, imports, and exports that are central to the prevailing theories and econometric models developed to test these theories. This may, of course, be a source of weakness, as TuCs engage in policy debates with powerful elites and the academic establishment (on power over ideas, see Carstensen and Schmidt 2016; Widmaier 2016; Steinberg 1998). However, the ambiguities, gaps, and uncertainties in international trade theory highlighted above afford TuCs a margin of autonomy that results in beliefs that do not mirror the academic consensus or majority view. In the analysis below, I describe and compare the beliefs that the AFL-CIO and the TUC have used to justify their opposition or support to FTAs. At the same time, I take advantage of the uniquely rich verbatim exchanges between the AFL-CIO and the US officials included in publicly available transcripts from the US Congress Hearings on trade policy to highlight the decisive role of agents' beliefs in the explanation of behaviour.

Since the late 1960s, the AFL-CIO has consistently resisted trade liberalisation and the TUC has consistently supported it, both without significant internal dissent. This applies particularly to the most heated debate on trade in the recent US history, the debate on NAFTA where, as Chase (2003) 
shows, no labour union testified to support the treaty (on this consensus, see also Shoch 2000). In 2008, all nineteen AFL-CIO officials that I contacted described the NAFTA treaty as bad or very bad for American workers. The other official was undecided. Similarly, I have not found signs of internal dissent within the TUC in the period considered here; not a single voice against trade liberalisation in press articles or at the yearly TUC annual conference. When I asked about the EU enlargement in 2008 , fourteen out of my twenty-three TUC officials described it as very good or good for workers and, of the eight who thought it was bad for workers, only two - an official at the National Union of Journalists and another one from Advance, a union that represents employees at Bank Santander UK - thought that it should not have been signed. Since the US and the British economic structures are quite similar and have developed in a similar way in recent decades as a result of de-industrialisation, since the membership composition by sector of the AFL-CIO and the TUC are very similar and have evolved similarly over the years, the lack of overt divisions within the US and the British trade union movements strengthen the argument that contrasts in the justifications used to oppose and support trade liberalisation rest, to a large extent, in different belief configurations.

The article shows that the US and the British TuCs' approach to FTAs is driven by the salience and meaning that trade dependence and trade balance have for them. The TUC has accepted trade liberalisation projects mainly because it is convinced that British prosperity depends on foreign markets and because this belief has weighed more in their minds than another belief, also shared by many British trade union leaders, especially in the metal sector, that imports and trade deficits have cost British workers many jobs. Hence the TUC's long-standing liberal attitude to foreign trade, which was contradicted only in the pre-FTAs 1980s, when, harassed by Thatcher's conservative government and shocked by the erosion of the UK's trade surpluses in manufacturing, the TUC briefly became protectionist (on foreign trade, see Rowthorn and Coutts 2004). By 1990, the TUC had already reverted to its traditional liberal approach to trade (see TUC annual congress reports from 1980 to 1990$)$. 
In the AFL-CIO's approach to FTAs, data on the balance of trade have played as central a role as has trade dependence in the TUC's approach. As I show below, since the late 1960s, the AFL-CIO has singled out trade liberalisation as the prime culprit for surges in imports and trade deficits, which it sees as largely responsible for the deterioration of living standards of the US workers. These justifications stand in contradiction to some cherished tenets in the mainstream literature on the economics of international trade. For instance, this literature agrees that no generalisable statement can be made about the impact of trade liberalisation on the balance of trade or about the impact of imports and trade balances on jobs and wages, including those of the less-skilled workers of advanced economies (Feldstein 2008; Samuelson and Nordhaus 2005: 601; Freeman 1995). Also, although there is more debate on the specific impact of trade liberalisation and rising imports on the lives of the US workers, leading economists still overwhelmingly advocate free trade over protection and believe that the overall effects of trade liberalisation, including NAFTA, have been positive for the US citizens (i.e. University of Chicago's Book School of Business's survey of academic economists). This claim finds confirmation in theory and research published in the leading economics journals that have not established more than a trivial negative impact of trade liberalisation and imports, including those originating in countries with which the US had signed FTAs, and including the highly controversial NAFTA treaty (e.g. Haskel et al. 2012; Burfisher et al. 2001). This research shows that the negative impact of trade liberalisation has been concentrated on displaced workers and only in very specific industrial sectors (e.g. textiles, footwear), locations, and occupations, although the authors concede that the effect on these groups has been very negative (McLaren and Hakobyan 2010; Kletzer 1998). Finally, while some research has noted a significant negative impact of imports from China on the lives of the US workers (Acemoglu et al. 2016; Balsvik et al. 2015; Ebenstein et al. 2009), the magnitude of this negative impact is still disputed (e.g. Edwards and Lawrence 2013) and is circumscribed to the period after the year 2000. In the three decades before China became a full trading partner of the US, however, the AFL-CIO justified protectionist demands and opposition to FTAs, moved by the conviction that trade liberalisation would cause a surge in imports and trade 
deficits, and that these trade deficits and imports were having and would have dramatic negative effects on the US workers. Though couched in sound economics language and arguments and backed with abundant empirical data, the discrepancy between the AFL-CIO's arguments for rejecting FTAs and the dominant understandings at the time when the AFL-CIO's arguments were first formulated (e.g. Burfisher et al. 2001; Cline 1997; Lustig et al. 1992; Krugman and Baldwin 1987) and lack of adequate data and conclusive empirical evidence to support these arguments (see below and Mitchell 1970) underlines the role of interpretation and beliefs in the explanation of the TuCs' approach to FTAs.

Beliefs, sometimes true, sometimes wrong, and most of the times based on insufficient and ambiguous information, underlie behaviour - a fact that becomes most obvious when different but equally rational political actors choose different diagnostics of the same reality. It is not the UK's strong trade dependence that has led the TUC to support trade liberalisation, but the TUC's attention to the UK's trade dependence and its strong belief that the UK's trade dependence should be the primary consideration when approaching FTAs. Similarly, it is not the US trade deficit or the US's high volume of imports that has caused the AFL-CIO to oppose FTAs but the AFL-CIO's attention to this trade deficit and imports and a sustained belief that they hurt the US workers significantly and neutralise whatever positive impact foreign trade may have for the US economy. Explaining why these beliefs formed is important but beyond the scope of this article (see Chwieroth 2010 for work that accomplishes that with respect to financial liberalisation).

\section{Interpretation and trade union approaches to trade liberalisation projects}

The US and the EU trade liberalisation agreements with emerging economies examined in this article were signed between 1985 and 2012. To reconstruct how the US and the British trade unions approached free trade and related agreements, I have examined numerous documents produced over the years. This exploration underlies the systematic analysis of a selected body of documents below. This analysis focuses on thirteen official statements (e.g. at the US Congress Hearings) and press 
releases issued by the AFL-CIO and its representatives. They concern NAFTA and the FTAs with Chile, Jordan, Singapore, the Dominican Republic, Peru, Oman, South Korea, and Morocco. It also focuses on the verbatim transcripts of all TUC annual conferences between 1997 and 2012. I use a more general source of information for the TUC than for the AFL-CIO because, in contrast to the AFL-CIO, the TUC has rarely released statements concerning FTAs. In view of this silence, transcripts of the TUC's annual conference offer at least the opportunity to examine the TUC's general positions on foreign trade and its interpretation of changes affecting the working class. After first reading all the documents to get a sense of structure and content, I conducted word searches of these conferences' transcripts using the words or phrases 'trading', 'trade in', 'trade with', 'trade deficit', 'world trade', 'trade balance', 'balance of trade', 'exchanges', 'markets', 'enlargement', 'Central Europe', 'Eastern Europe', and 'global'. I then transcribed the text preceding and following these words, as bounded by the specific theme that was being discussed (generally one paragraph to one page long).

For all the AFL-CIO documents and all the TUC text blocs selected from the transcripts pertaining to its annual conference, I wrote down all phrases related to 1) descriptions and 2) evaluations of 3) free trade in general and 4) specific FTAs or the EU enlargement. Tables 2 and 3 provide the list of phrases obtained through the coding process. In total, I coded 84 statements for the AFL-CIO (44 concerning trade liberalisation in general, 40 concerning the specific FTAs) and 49 statements for the TUC (47 concerning trade liberalisation in general, 2 concerning the EU enlargement). These statements encompass the full range of descriptive and evaluative statements in these documents and also in most documents related to the AFL-CIO and the TUC to which I have had access.

Counts of absolute or relative frequencies must be handled with caution for these are not comparable or representative samples and types of documents and, also, because one cannot assume independence between different statements. The AFL-CIO, for instance, uses a template in some of its statements at the Congress Hearings, which it then adapts to address the specifics of the trade 
agreements under consideration. Finally, the fact that the AFL-CIO's documents justify opposition to FTAs (except the FTA with Jordan) means that negative descriptive or evaluative statements should logically outnumber the positive ones. Because of the considerations above, Tables $\mathbf{2}$ and $\mathbf{3}$ report the statements but not the frequencies corresponding to each of them. In what follows I refer to these counts only if it unambiguously helps illuminate the contrast between the AFL-CIO and the TUC. Statements made by both the AFL-CIO and the TUC are placed in the middle of the corresponding row, whereas statements only made by one of the TuCs are placed in the column corresponding to that TuC.

\section{[Tables 2 and 3]}

The analysis confirms that the TUC has not discussed FTAs at its annual conference. Only the enlargement of the EU to Central and Eastern Europe in 2004 raised some interest, and only in 2003. I found only two descriptive or evaluative statements and both were positive. This contrasts with the very close monitoring to which the AFL-CIO has subjected FTAs since the mid-1980s. The TUC's lack of engagement with FTAs is consistent with a taken-for-granted assumption that Britain has no alternative to open markets. The first row of Table 2 shows that the AFL-CIO documents never speak to the significance of foreign markets to the US economy, whereas those from the TUC's annual conference do. In fact, a detailed presentation of all verbatim statements would show that nineteen of the TUC delegates' forty-seven statements that refer to trade liberalisation are of this kind.

As one would expect, the US and the British framing of the positive and the negative consequences of free trade overlaps. Tables 2 and $\mathbf{3}$ show, however, that the AFL-CIO mainly perceives trade liberalisation as a source of problems whereas the TUC delegates see both positive and negative aspects. The contrast between the AFL-CIO and the TUC is particularly evident with respect to the expectations regarding trade liberalisation's net impact on jobs. The AFL-CIO only perceives job losses, whereas the TUC perceives both losses and gains. A thorough comparative 
reading of the different statements and documents produced by the AFL-CIO and the TUC over the years in diverse settings and about different topics, combined with the objective information provided in Tables $\mathbf{2}$ and 3, reveals that the AFL-CIO has focused almost solely on the past and potential costs of trade liberalisation. Neither the content of the FTAs signed by the US and the EU nor different challenges faced by the US and the British manufacturing sectors can account for the observed contrasts between the AFL-CIO and the TUC.

It is worth emphasising, for instance, that since 1990 repeated motions at the TUC's annual congress have called the government to do something about the crisis in the manufacturing sector. These motions reveal an interpretation of the role of trade liberalisation in this crisis not very different from that of the AFL-CIO, with imports made partly responsible for a massive destruction of manufacturing jobs. The main contrast between the AFL-CIO's and the TUC's discourse, however, is that the TUC also attributes responsibility to other variables (e.g. high interest rates, a strong pound). Contrasts also emerge with respect to proposals for overcoming the crisis, for the TUC does not call for protection, as the AFL-CIO does, but emphasises instead the need to invest in quality and productivity.

The different ways of framing the crisis in the manufacturing sector highlighted in the last paragraph testify to the central role that perceptions of and beliefs about trade dependence play in how the US and the British TuCs frame FTAs. Convinced that the UK depends on foreign trade, the TUC has rarely discussed trade liberalisation agreements, and when it has, it has endorsed them. Its main effort has been directed toward minimising the costs and maximising the benefits derived from the FTAs. Less concerned than the TUC about the economic significance of foreign markets for the national economy, the AFL-CIO has concentrated its attention on the FTAs' labour content and on their potential impact on imports, trade balance, and the lives of workers. For most of the $20^{\text {th }}$ century the US enjoyed large trade surpluses. These surpluses gave the US trade unions little reason to oppose free trade. When surpluses turned into deficits, however, the perception that imports and trade deficits pose a major threat to workers' lives, combined with the perception that the US economy did not 
depend much on foreign trade, led the AFL-CIO to advocate foreign trade restrictions and oppose ambitious trade liberalisation projects. One gains a clearer understanding of the meaning that trade imports and deficits have played in the AFL-CIO's approach to trade policy for the last four decades through an examination of the AFL-CIO's shift from liberal to protectionist views in the 1960s. It was then that the script that has informed the AFL-CIO's approach to NAFTA and later FTAs was born.

\section{Imports, trade balance, and jobs: the AFL-CIO's turn to protectionism}

The Congress Hearings on the Trade Expansion Act (TEA) and on Tariff and Trade proposals in 1962 and 1970 illustrate the enduring power of negative perceptions of imports and trade deficits and the role these played in the AFL-CIO's shift to protectionism. Well into the second half of the $20^{\text {th }}$ century, protectionist policies were advocated mainly by the Republican Party while the Democratic Party and its labour allies sided with free trade (Hiscox 1999; Northrup and Turney 2003; Keech and Pak 1995; Nivola 1986). The Democratic Party's liberal attitude coincided with a long period (19251971) of trade surpluses. In the 1960s, however, imports surged and already in 1971 the US began to post trade deficits. While small at the beginning, by 1978 the deficit had already reached 28.5 million dollars. Between 1978 and 1982 the situation improved somewhat, but then trade deficit climbed again, this time uninterruptedly. Early in the second millennium, it peaked at close to 6\% of the GDP. The Democratic Party and the US labour movement broke with tradition and embraced protectionism only when the value of imports began to rise at a fast rate in the mid- to late 1960s (Keech and Pak 1995; Mitchell 1970; Nivola 1986: 588).

The literature has paid little attention to this momentous and lasting shift. The US economy's dependence on foreign markets did not change noticeably during the 1960s. There were also no institutional political changes during that short period that would account for the change. The US economy was solid, with unemployment at record low levels (i.e. 1968 posted the lowest unemployment rate in 15 years) and rising real wages (US Labor Bureau Statistics). Last but not least, 
unionisation rates among wage and salaried workers, which had steadily declined since the early 1950s, stabilised during the 1960s.

Close inspection of the 1962 and 1970 Congress Hearings above, complemented by a systematic examination of all the AFL-CIO's Executive Council statements released in that decade (Fink 1977) and of newspaper articles obtained through New York Times searches using keywords such as 'US jobs' and 'trade policy', reveals that the surge in imports during the 1960s was the key variable underlying the shift in the AFL-CIO's position on trade liberalisation. Relative to the previous decade, when the rise in imports affected mainly the textile, apparel, and footwear sectors, the surge of imports in the 1960s affected the steel industry most intensely. Underlying the increase in purchases from abroad was, first of all, increased demand, which coincided with a thriving economy. In October 1968, the US had posted a record $80^{\text {th }}$ consecutive month of business expansion. The steel industry, in particular, was functioning at full capacity and the extra demand had to be met through imports. This moved Republican Congressman Thomas B. Curtis of Missouri to say that, in fact, without imports, steel supplies would have been extremely tight and 'many jobs would have been lost.' According to him, there was 'strong reason to believe from unpublished data that steel mills accounted for a large portion of the imports of steel mill products in 1965 and $1966{ }^{\prime}{ }^{4}$ Demand in excess of domestic supply also made products more expensive and imports more competitive. Inflation was in fact one of the most pressing economic problems faced by the Johnson and Nixon administrations. Other factors unrelated to economic expansion also impacted on trade balance. Relative factor endowment changes affecting semi-skilled labour combined with on-going trade liberalisation and greater access to advanced technology in developing countries like Japan reduced the US's international comparative advantage in this branch of activity and contributed to the increase in steel imports (Midford 1993). Last but not least, acrimonious conflict between capital and labour in the steel sector during the decade led to almost yearly spurts of demand, as companies felt compelled to hedge buying in anticipation of strikes, which more often than not did not materialise. 
These surges in imports, which went as far back as a long strike in 1959, could not have been met through domestic production.

Although the share of steel imports over total production increased during the decade and became higher than in other industrial sectors, it remained at under $15 \%$ of total domestic consumption. And yet, just as in other industrial sectors, alarmed concern and increasingly louder demands for protectionist measures ensued. The overlap between trends in imports and trade balance and protectionist demands is perfect. In the steel industry, the dramatic shift from a slight surplus in 1962 to a deficit in 1968 was followed by producer demands for a levy on imports in February 1967. Barely eight months later, the Steelworkers Union followed suit. More generally, the AFL-CIO veered to protectionism as the US's traditional trade surplus evaporated between 1964 and 1969. In 1970, a year before the US posted its first trade deficit, the AFL-CIO joined the anti-trade coalition. Although unions in many economic sectors supported the shift, the Steelworkers Union of America led the movement, its power within the AFL-CIO significantly reinforced under Abel's leadership and following the banning of the powerful and more liberal United Auto Workers (UAW) association.

The main reasoning behind the AFL-CIO's move, as would be the case for the following four decades, was that the surge of imports resulted from trade liberalisation and that massive imports posed an enormous threat to jobs and wages. Both were questionable assumptions and highlight the role of interpretation in the explanation of the AFL-CIO's shift to protectionism. As I describe above, while trade liberalisation combined with changes in relative factor endowment are part of the story, unmet demand in a period of economic expansion and hedging against the risk of labour unrest also played a big role in the explanation of the rise of imports during the 1960s. In a New York Times article published on 4 April, 1965, a steel executive reported that not even Japanese exporters knew whether increased access to the US market reflected greater competitiveness of Japanese products or the accumulation of stock by the US producers concerned about the possibility of a strike in the steel sector. ${ }^{5}$ The AFL-CIO could not possibly know or calculate how much of a role trade liberalisation was playing in the trend in the balance of trade. This makes the AFL-CIO's selection and 
interpretation of the information that was available crucial to the explanation of its shift to protectionism.

Similarly, the AFL-CIO could not possibly know or calculate what impact imports and a looming trade deficit were having or would have on employment. There is no question that imports were responsible for the loss of jobs in some economic sectors and that they weakened the trade union's bargaining position on wages and other benefits. But at the time other variables, like automation or increased competition between semi-skilled workers, were simultaneously transforming the US labour market and also impinged on employment, wages, and benefits. As I show below, however, the AFL-CIO became convinced that free trade was a major threat to the workers' living standards.

The tracing of unemployment to trade liberalisation, the apportioning of variation in imports and unemployment between shares due to trade liberalisation and shares due to other causes required a 'theory'. The 'theory' that the AFL-CIO relied on in the 1960s traced the surge in imports during that period overwhelmingly if not totally to trade liberalisation and then traced job losses overwhelmingly if not totally to the surge in imports. Based on this interpretation, the AFL-CIO had then to decide on a course of action. This decision required another 'theory', one concerning the impact on jobs (and wages) of protectionist versus free-trade policy and of protectionist versus alternative policies beneficial to workers (e.g. improved trade assistance schemes). The theory that the AFL-CIO used systematically discounted, for instance, potential job losses caused by retaliation measures taken by other countries, found free trade too costly, and concluded that tariff and related forms of trade protection would benefit workers more than alternative measures (Bureau of Labor Statistics 1971).

In 1962, the US Congress approved the TEA, a bill that gave the President the authority to negotiate sweeping tariff reductions. At the Congress Hearings that preceded the approval of the TEA, the AFL-CIO was represented by its president, George Meany. Meany's statement and the attached memorandum were favorable to the TEA. They were primarily addressed to those concerned about 
the impact that the elimination of tariffs could have on foreign imports and on the US industry's grip on the home market.

Meany stressed the economic importance of foreign markets and refuted the existence of a necessary link between rising imports and dramatic job losses. Against pessimists, he highlighted that the TEA would create jobs: 'Little is said about the impact on our economy of the goods we export. You can see an import - an export is only a statistic. Yet the records show that there are 10 jobs related to our exports for every 1 job that might be lost because of our imports.' Meany showed strong confidence in the US industry's capacity to remain competitive despite high wages.

The backbone of the AFL-CIO's rhetoric, however, was a rebuttal of the import-job loss argument. Meany stressed a lack of correlation between imports and unemployment and that, in fact, more jobs had been created than destroyed. He also disputed the idea that imports necessarily competed with local products (the supporting memorandum in fact claims that $60-70 \%$ were noncompetitive). Many of those imported goods, one reads, were in fact indispensable intermediary inputs in local production. Further, the AFL-CIO argued that even when imports compete with local production, it is wrong to assume that a ban on those will necessarily lead consumers to switch to local substitutes, for their price and quality may be unattractive. Finally, Meany pointed out that in sectors like transportation and distribution the elimination of barriers to trade means business and, therefore, jobs.

Throughout his presentation, Meany acknowledged that jobs would be lost as a result of the gradual elimination of trade barriers and agreed on the need to remedy this. In his view, however, restrictions on trade would cause more harm than good and he proposed instead to use judiciously the old escape clause included in the Trade Agreements Act, a generous trade adjustment assistance programme, and a proactive policy aimed at the inclusion of international labour standards in trade agreements.

In 1962, the US retained a small trade surplus in goods and services. Then, during the 1960s, imports increased more than exports and by 1970 the trade surplus had all but vanished. 
Unemployment was still below $4 \%$, however. In fact, employment losses during the decade, even in the very narrowly defined (e.g. using 4- and 5-digit classifications) and 'hardest' hit industries, represented less than three percent of average employment in these industries (see Mitchell 1975: 369-72; Bureau of Labor Statistics 1971; Stewart 1971). Not significant changes in employment levels but an uncompromising attitude to rising imports led to the protectionist mobilisation of the AFL-CIO. This belief overrode Meany's balanced appraisal of the effects of trade liberalisation of eight years earlier.

The Hearings on Tariffs and other Trade Measures that preceded the Trade Act of 1970, restating the exact same arguments and conclusions as the AFL-CIO's Report of the Economic Policy Committee on International Trade of the same year (Fink 1977), displayed the AFL-CIO's new approach to trade policy in full light. Although George Meany was still at the helm, it fell on the longtime and loyal AFL-CIO officials, Andrew Biemiller, Director of the Department of Legislation, and Nathaniel Goldfinger, Director of the Department of Research, to represent the AFL-CIO this time. Their statement informed of the resolution adopted by trade unionists assembled at the AFLCIO's 1969 biennial convention. Together with the attached written materials the statement conveys that the panicked perception of a 'rising tide of imports, imports rising much faster than exports during the second half of the 1960s' was indeed what moved the trade union confederation to back down from its previous pro-trade position. The tide, said the AFL-CIO, had affected a wide range of economic sectors, including steel, autos, trucks and parts, clothing, footwear, and glass (Root and Mennis 1976). The AFL-CIO's discourse now paid no attention to potential advantages connected to the conquest of foreign markets. The US TuC also blamed trade liberalisation under the TEA for the full rise of imports and overlooked the role of other factors, such as inflation (Mitchell 1970: 275).

The AFL-CIO's presentation shows that attribution of sole responsibility to trade liberalisation measures for the rising imports and the tripling of imports itself, instead of objectively measured negative consequences of these imports, caused the AFL-CIO's reversal of its traditional position on trade liberalisation. While the AFL-CIO stressed that imports were costing jobs, its discourse betrayed 
that this was more assumption than fact. Its spokespeople said that 'the US position in world trade deteriorated in the 1960s, with adverse impacts on American workers, communities, and industries', or 'the fact of increasing job losses is clear'. But then, they would concede that they were simply relying on reasoned assumptions: 'The deterioration of the US foreign trade position has obvious impacts on jobs, on the collective bargaining strength of unions, on wages and on the labour standards of affected industries.' In truth, they had no objective information to back the attribution: 'Precise statistics on the job-loss of imports are not available and estimates of the job-impact of exports are only rough guesses that are clouded by the increasing complexity of trade patterns.' This statement echoed the Report of the Economic Policy Committee on International Trade, published that same year, in which one reads: 'Precise information on the job-loss of imports is not available and estimates of the job-impact of exports are only rough guesses that are clouded by the increasing complexity of trade patterns. Unfortunately, foreign trade experts usually show little interest and even less knowledge about the employment impacts of developments in foreign trade. Yet, the fact of job losses is clear' (Fink 1977, p.1983). The AFL-CIO was aware of the fact that the determination of a causal linkage between trade and wages or other variables that impact on the lives of workers is a complex matter. In practice, however, the AFL-CIO was blind to these subtleties when justifying support for protection and harnessed estimates of the link between import and jobs that overlooked this technical complexity and the role of other factors in the explanation of unemployment (Bureau of Labor Statistics 1971: 498). The first standard approach that the AFL-CIO used to estimate the effect of imports on jobs was to attribute all net employment loss to imports. The second one was to take the dollar value of imports in specific sectors and then, under the assumption that other factors remained constant, calculate the number of workers that would be needed to domestically produce value equivalent to these imports. As the Bureau of Labor Statistics stated at the time, 'the assumption that other factors are constant is, of course, unrealistic' (Bureau of Labor Statistics 1971: 498).

All complexity related to the economic implications of imports outlined by Meany in his 1962 statement was abandoned here in favour of a simple faith in the catastrophic impact of imports, a faith 
that, just like any faith, needed no data: 'Solutions cannot await additional long-range studies. Action must start now. Workers, whose jobs are at stake - from a rising tide of imports, frequently produced with modern technology at wages 50 percent to 90 percent below US levels - must not be told to wait another year or two or three for the findings of yet another study, while the displacement of US production and export of American jobs accelerates.'

In sum, the AFL-CIO turned protectionist out of fear of rising imports. This fear was expressed by the AFL-CIO's highest officials during the Congress Hearings above but also in several AFL-CIO Executive Council Statements published since the second half of the 1960s (Fink 1977: 1977-1995); it can also be found in statements by representatives of most of the industrial sectors, like textile/apparel and steel, where imports were growing fast (see Bureau of Labor Statistics 1971: 289319 for views from the Steel sector and from the Textile and Apparel sectors expressed in exactly the same terms). Since then, and for over forty years, the AFL-CIO has consistently linked trade liberalisation to trade deficits and skyrocketing imports, and trade deficits and large imports to havoc among the US working class. The consistency of this discourse over time, whether directed to expert audiences in academia and politics (e.g. the Congress) or to the public in general, the effort invested in developing complicated estimating procedures and providing numbers to buttress the argument, the stability of the discourse over time despite the US's growing trade dependence, a changed sectorial structure of the trade union movement (much less centred in manufacturing), and more labour-friendly FTAs, suggest that this was not 'cheap talk' but a deeply internalised belief.

\section{Conclusion}

Economic theory and the historical record suggest that barriers to the movement of goods, capital, and services can have devastating economic and political consequences. It is thus important to locate the factors that tilt the balance in the direction of liberalisation or in that of protectionism and the variables that explain attitudes to free trade among different social groups. This is particularly relevant in the contemporary context, where active resistance to core aspects of globalisation (e.g. 
supranational governance, international trade and investment, international mobility of workers) appears to be on the rise in the Western world. The high degree of controversy surrounding trade liberalisation agreements concluded after 2010 (e.g. the Comprehensive Economic Trade Agreement (CETA), the Trans-Pacific Partnership (TPP)) or still in the course of being negotiated (e.g. the TransAtlantic Trade and Investment Partnership (TTIP)) are examples of this growing resistance. In particular, the belligerent approach toward TTIP by many European trade union confederations, alone or in coalition with civil organisations, is worth noting, for it may signal a qualitative shift in how they approach trade liberalisation. One of this study's implications is that the explanation for the increasing resistance to globalisation will benefit greatly from an interpretive analytical approach that privileges the examination of the actors' frames and beliefs.

This article indeed aligns with constructivist approaches in IR and IPE that place actors' interpretations at the centre of explanation. In the period from 1985to 2012 examined here, the TUC and the AFL-CIO have periodically invoked structural factors to justify supporting or opposing FTAs. I have argued, however, that not the structural factors' actual impact on the economy or the lives of the US and the British workers, but the salience of and the meaning attached to these structural factors is what, in the end, accounts for the AFL-CIO's opposition and the TUC's support to FTAs in the period examined here.

The article shows that perceptions of trade dependence and beliefs about the relationship between trade policy and trade balance and between the latter and the workers' living standards account for why the AFL-CIO has opposed FTAs whereas the TUC has supported them. The interpretive approach used in this article calls for pushing the analysis towards examining how trade dependence and trade balance have come to weigh as heavily as they do in the TuCs' approach to trade policy. In particular, systematic archival research and interviews may contribute to reconstructing the social networks, institutions and ideas that contributed to the AFL-CIO's approach to trade liberalisation and that still nurture this approach. Business clearly played a role in developing and diffusing among workers and their union representatives the arguments on which the US labour 
has relied since the mid-1960s, as conveyed in a New York Times news article of 1966, where a spokesperson for steel importers charged domestic steel-makers with making a 'massive effort' to mislead their workers by telling them foreign steel was causing their difficulties. ${ }^{6}$ One should also examine the role that think tanks like the Economic Policy Institute may have played in providing empirical support to the AFL-CIO's claims and in reproducing their fear of trade deficits and imports.

This view of trade deficits and imports as inherently bad, however, finds its roots back in time and is certainly prevalent around the world. The TUC's representatives in the United Kingdom express similar fears, only balanced by the perception that the UK depends on foreign markets. One can speculate about the role of loss aversion in explaining this perception in the British and the US TuCs (on loss aversion and trade policy, see Freund and Özden 2008). Alternatively, a sceptical view, anchored in recent scholarship about what counts as established knowledge, would call for revisiting the scientific debate around the myth surrounding trade deficits and evaluating the extent to which it is really a myth or has been constructed as such by pro-free trade interests.

\section{Acknowledgments}

I am very grateful to the JIRD reviewers, to Jeffrey Checkel, Liesbet Hooghe, Gary Marks, Juan Fernández, Francesco Duina, Thomas Risse, Robert Fishman, and Bart Manikowski for stimulating feedback to previous versions of this paper. I also thank the Universidad Carlos III de Madrid, the Institut Barcelona d' Estudis Internacionals (IBEI), the Wissenchaftszentrum Berlin für Sozialforschung (WZB), the Kollegforschungsgruppe (KfG) 'The Transformative Power of Europe' at the Freie Universität Berlin, and the Institut für Soziologie at the Freie Universität Berlin, for having provided me with the ideal settings for work on this project.

\section{Notes}

1 The list of participant unions is available upon request. 
2 see John Monks (1998), TUC Congress Verbatim Report, p. 53

3 John Monks (General Secretary, ETUC, 13 November, 2006, 'Speaking Note' at the DG Trade Conference Global Europe: Competing in the World, the Way Forward.

4 'No Damage found in Steel Imports', New York Times (1 May, 1967).

5 'Japan increases Exports', New York Times (17 April, 1965).

6 New York Times (10 March, 1966; for similar accusations see also 'Steel Importers Assail US Mills', New York Times 22 October, 1965). 


\section{Primary sources for content-analysis}

\section{AFL-CIO}

Donahue, Thomas R. (1993) 'Statement before the Senate Commerce, Science and Transportation Committee on the North American FTA’ (6 May, 1993).

Sweeney, John (2001) ‘Jordan Free Trade Agreement: Statement of John J. Sweeney, President, AFLCIO, Washington, DC: Hearing before the Committee on Finance', United States Senate, One hundred-seventh Congress, First Session (21 March, 2001).

Labor Advisory Committee for Trade Negotiations and Trade Policy (2003) 'The US-Chile and the US Singapore Free Trade Agreements' (28 February, 2003).

AFL-CIO (2003) 'US - Chile Trade Agreement Rolls Back Progress in Trade Policy and Tramples on Workers' Rights' (6 June, 2003).

Lee, Thea M. (AFL-CIO) (2005) 'Dominican Republic-Central America Free Trade Agreement. Hearing before the Subcommittee on Commerce, Trade, and Consumer Protection of the Committee on Energy and Commerce', House of Representatives, One Hundred Ninth Congress, First Session (28 April, 2005).

AFL-CIO (2005). 'Opposition to the Dominican Republic-Central American Free Trade Agreement', Resolution 50, submitted by the AFL-CIO Executive Council, AFL-CIO Annual Convention.

AFL-CIO (2006) 'Statement by AFL-CIO President John Sweeney on Passage of Oman FTA in House' (20 July, 2006).

Gibson, Brett (AFL-CIO) (2006) 'Implementation of the United States-Peru Promotion Agreement Hearing before the Committee on Ways and Means', US House of Representatives, One Hundred Ninth Congress, Second Session (12 July, 2006).

Samuel, William (Director: Department of Legislation, AFL-CIO) (2007) 'Legislative Alert', Letter sent to Congress Representatives in connection with the US-Peru Free Trade Agreement (28 September, 2007). 
AFL-CIO (2007) 'Statement by AFL-CIO President John Sweeney on Passage of Peru FTA' (8 November, 2007).

AFL-CIO (2008) 'Statement by AFL-CIO President John Sweeney on US-Colombia Free Trade Agreement' (4 July, 2008).

AFL-CIO (2010) 'Statement by AFL-CIO President Richard Trumka on Korea Trade Deal' (9 December, 2010).

Lee, Thea M. (AFL-CIO) (2011) 'US-Korea Free Trade Agreement Hearing before the Committee on Finance', United States Senate, One hundred twelfth Congress, First session (26 May, 2011).

TUC

TUC Annual Congress (1997-2012). Verbatim Transcripts.

\section{References}

Abdelal, Ravi (2009) Capital Rules, Princeton: Princeton University Press.

Abdelal, Ravi, Craig Parsons and Mark Blyth, eds (2010) Constructing the International Economy, Ithaca: Cornell University Press.

Acemoglu, Daron, David Autor, David Dorn, Gordon Hanson and Brendan Price (2016) 'Import Competition and the Great Employment Sag of the 2000s', Journal of Labor Economics 34(1): 145-95.

AFL-CIO (1978) 'An American Trade Union View of International Trade and Investment', in US Senate, Committee on Finance. Multinational Corporations, 80, Washington: US Government Printing Office. 
Alesina, Alberto, Enrico Spolaore and Romain Wacziarg (2005) 'Trade, Growth, and the Size of Countries', Volume 1B in Philippe Aghion and Steven N. Durlauf, eds, Handbook of Economic Growth, 1500-42, New York: Elsevier.

Balsvik, Ragnhild, Sissel Jensen and Kjell Salvanes (2015) 'Made in China, Sold in Norway: Local Market Effects of an Import Schock', Journal of Public Economics 127: 137-44.

Bieler, Andreas and Adam David Morton (2008) 'The Deficits of Discourse in IPE: Turning Base Metal into Gold', International Studies Quarterly 52(1): 103-28.

Blyth, Mark (2002) Great Transformations, Cambridge: Cambridge University Press.

Blyth, Mark (2013) Austerity: The History of a Dangerous Idea, Oxford: Oxford University Press.

Brady, David, Martin Seeleib-Kaiser and Jason Beckfield (2007) 'Economic Globalization and the Welfare State in Affluent Economies, 1978-2001', American Sociological Review 70(6): $921-48$.

Braun, Benjamin (2014) 'Why Models Matter: The Making and Unmaking of Governmentality in Macroeconomic Discourse', Journal of Critical Globalization Studies 7: 48-79.

Bureau of Labor Statistics (1971) 'Foreign Trade and Employment', in United States International Economic Policy in an Interdependent World. Papers Submitted to the Commission on International Trade and Investment Policy and Published in Conjunction with the Commission's Report to the President, Washington: US Government Printing Office.

Burfisher, Mary, Sherman Robinson and Karen Thielfelder (2001) 'The Impact of NAFTA on the United States', Journal of Economic Perspectives 15(1): 125-44.

Burgoon, Brian (2001) 'Globalization and Welfare Compensation: Disentangling the Ties that Bind', International Organization 55(3): 509-51.

Burgoon, Brian and Wade Jacoby (2011) 'Patch-Work Solidarity: Describing and Explaining US and European Labour Internationalism', Review of International Political Economy 11(5): 84979. 
Cameron, David R. (1978) 'The Expansion of the Public Economy: A Comparative Analysis', American Political Science Review 72(4): 1243-61.

Carstensen, Martin and Vivien Schmidt (2016) 'Power through, over and in ideas: conceptualizing ideational power in discursive institutionalism', Journal of European Public Policy 23(3): $318-37$.

Chase, Kerry A. (2003) 'Economic Interests and Regional Trade Agreements: The Case of NAFTA', International Organization 57(1): 137-74.

Checkel, Jeffrey (1998) 'The Constructivist Turn in International Relations Theory', World Politics 50: $324-48$.

Chwieroth, Jeffrey (2010) Capital Ideas: The IMF and the Rise of Financial Liberalization, Princeton, NJ: Princeton University Press.

Cline, William (1997) Trade and Income Distribution, Washington: Institute of International Economics.

Coyle, Diane (2014) GDP: A Brief but Affectionate Story, Princeton: Princeton University Press.

Duina, Francesco (2006) The Social Construction of Free Trade, Princeton: Princeton University Press.

Ebenstein, Avraham, Ann Harrison, Margaret McMillan and Shannon Phillips (2009) 'Estimating the Impact of Trade and Off-shoring on American Workers Using the Current Population Surveys', NBER Working Paper 1517: 1-46.

Edwards, Lawrence and Robert Lawrence (2013) Rising Tide: Is Growth in Emerging Economies Good for the United States, Washington: Peterson Institute for International Economics.

Ehrlich, Sean (2007) 'Access to Protection: Domestic Institutions and Trade Policy in Democracies', International Organization 61(3): 571-605.

Feldstein, Martin (2008) 'Resolving the Global Imbalance: The Dollar and the US Savings Rate', Journal of Economic Perspectives 22(3): 113-25. 
Finnemore, Martha and Kathryn Sikkink (2001) 'TAKING STOCK: The Constructionist Research Program in International Relations and Comparative Politics', Annual Review of Political Science 4: 391-416.

Fink, Gary M., ed. (1977) AFL-CIO Executive Council Statements and Reports, 1956-1975, Westport: Greenwood Press.

Freeman, Richard (1995a) 'Are New York Wages set in Beijing?', Journal of Economic Perspectives 9: $15-32$.

Freeman, Richard (1995b) ‘The Future for Unions in Decentralized Bargaining Systems: US and UK Unionism in an Era of Crisis', British Journal of Industrial Relations 33(4): 519-36.

Freeman, Richard (2007) America Works: The Exceptional US Labor Market, New York: Russell Sage Foundation.

French, John, Jonathan Cowie, and Scott Littlehale, eds (1994) Labor and NAFTA: A Briefing Book, Duke University: Duke-University of North Carolina Program in Latin American Studies.

Freund, Caroline and Çaglar Özden (2008) 'Trade Policy and Loss Aversion', American Economic Review 98(4): 1675-91.

Gitelman, Lisa (2013) Raw Data is an Oximoron, Cambridge, MA: MIT Press.

Hillary, John (2011) 'European Trade Unions and Free Trade: Between International Solidarity and Perceived Self-Interest', paper presented a the seminar on Trade Unions, Free Trade, and the Problem of Transnational Solidarity, Center for the Study of Social and Global Justice, University of Notthingham.

Hainmueller, J. and M. Hiscox (2006) 'Learning to Love Globalization: Education and Individual Attitudes toward International Trade', International Organization: 469-98.

Haskel, Jonathan, Robert Z. Lawrence, Edward E. Leamer, and Matthew J. Slaughter (2012) 'Globalization and U.S. Wages: Modifying Classic Theory to Explain Recent Facts', Journal of Economic Perspectives 26(2):119-40. 
Hiscox, Michael (1999) 'The Magic Bullet: The RTAA, Institutional Reform, and Trade Liberalisation', International Organization 53(4): 669-98.

Hiscox, Michael (2002) 'Commerce, Coalitions, and Factor Mobility: Evidence from Congressional Votes on Trade Legislation', American Political Science Review 96(3): 593-608.

Hofhansel, Claus (2001) 'Germany, Multilateralism, and the Eastern Enlargement of the EU', Centre for European Studies, Program for the Study of Germany and Europe, Cambridge: Harvard University, Working Paper 01.4.

Holloway, Harry (1979) 'Interest Groups in the Postpartisan Era: The Political Machine of the AFLCIO', Political Science Quarterly 94(1): 117-33.

Horng, Der-Ching (2003) 'The Human Rights Clause in the EU's External Trade and Development Agreements', European Law Journal 9(5): 677-701.

Hopf, Ted (2010) 'The Logic of Habit in International Relations', European Journal of International Relations 16(4): 539-61.

Hwang, Wonjae and Hoon Lee (2014) 'Globalization, Factor Mobility, and Compensation Policies', International Studies Quarterly 58(1): 92-105.

Jackson, Patrick Thaddeus and Daniel H. Nexon (2009) 'Paradigmatic Faults in International Theory', International Studies Quarterly 53(4): 907-30.

Jensen, J. B. and L. Kletzer (2005) 'Tradable Services: Understanding the Scope and Impact of Services Offshoring', Chapter 3 in Brookings Trade Forum 2005: Offshoring White-Collar Work, Washington D.C.: Brookings Institution.

Katzenstein, Peter (1985) Small States in World Markets: Industrial Policy in Europe, Ithaca: Cornell University Press.

Keech, William R. and Kyoungsan Pak (1995) 'Partisanship, Institutions, and Change in American Trade Politics', Journal of Politics 57(4): 1130-42.

Kirschner, Eli J. (2011) 'Fast Track Authority and its Implication for Labor Protection in Free Trade Agreements', Cornell International Law Journal 44: 386-415. 
Kletzer, Lori (1998) 'Job Displacement', Journal of Economic Perspectives 12(1): 115-36.

Krugman, Paul (2008) 'Trade and Wages, Reconsidered', Brooking Papers on Economic Activity (Spring).

Krugman, Paul and Richard Baldwin (1987) 'The Persistence of the US Trade Deficit', Brookings Papers on Economic Activity 1: 1-55.

Leamer, Edward E. (1995) The Heckscher-Olin Model in Theory and Practice, Princeton Studies in Economy and Finance 77, Princeton: Princeton University Press.

Lustig, Nora, Barry Bosworth and Robert Lawrence, eds (1992) North American Free Trade: Assessing the Impact, Washington: Brookings Institution.

Mansfield, Edward and Helen Milner (1999) 'The New Wave of Regionalism', International Organization 53(3): 589-627.

March, James and Herbert Simon (1958) Organizations, New York: Wiley.

McLaren, John and Shushanik Hakobyan (2010) 'Looking for Local Labor Market Effects of NAFTA', NBER Working Papers 16535: 1-48.

Mayda, A. and Dani Rodrik (2005) 'Why are some People (and Countries) more Protectionist than Others?', European Economic Review 49(6): 1393-430.

McNamara, Kathleen (1999) The Currency of Ideas: Monetary Policy in the European Union, Ithaca: Cornell University Press.

Midford, Paul (1993) 'International Trade and Domestic Politics: Improving on Rogowski's argument of political alignments', International Organization 47(4): 535-64.

Mitchell, Daniel (1970) 'Labor and the Tariff Question', Industrial Relations 1(3): 268-76.

Mitchell, Daniel (1975) 'Recent Changes in the Labor Content of US International Trade', Industrial and Labor Relations Review 28(3): 355-75.

Mullen, Andrew (2005) The British Left's Great Debate on Europe: The Political Economy of the British Left and European Integration, $\mathrm{PhD}$ thesis, University of Bradford, UK. 
Nivola, Pietro (1986) ‘The New Protectionism: US Trade Policy in Historical Perspective', Political Science Quarterly 101(4): 577-600.

Northrup, Cynthia Clark and Elaine C. Prange Turney, eds (1993) Encyplopedia of Tariffs and Trade in US History: The Encyclopedia. Vol. I, Westport: Greenwood Press.

Ohlin, Bertil (1967) Interregional and International Trade, Harvard Economic Studies 39, Cambridge, MA: Harvard University Press.

O'Rourke, Kevin and Richard Sinnott (2002) 'The Determinants of Individual Trade Policy Preferences', in Susan Collins and Dani Rodrik, eds., Brookings Trade Forum, 157-196, Washington D.C.: Brookings Institution.

Rankin, David (2004) 'Borderline Interest or Identity', Comparative Politics 36(3): 331-51.

Risse, Thomas (1988) Die Krise der Sicherheitspolitik. Neuorientierungen und Entscheidungsprozessen im politischen System der Bundesrepublik Deutschlands, Mainz: Grünewald-Kaiser.

Rodrik, Dani (2014) 'When Ideas Trump Interests: Preferences, World Views, and Policy Innovations', Journal of Economic Perspectives 28(1): 189-208.

Rogowski, Ronald (1987) Commerce and Coalitions: How Trade Affects Domestic Political Alignments, Princeton: Princeton University Press.

Rogowsky, Robert and Eric Chyn (2007) 'US Trade Law and FTAs: A Survey of Labor Requirements', United States International Trade Commission: Journal of International Commerce and Economics: 1-24, available online at https://www.usitc.gov/publications/332/journals/trade_law_ftas.pdf (last accessed on 10 January, 2017).

Root, Franklin and Bernard Mennis (1976) 'How US Multinational Corporations, Unions, and Government view Each Other and the Direction of US Policies', Journal of International Business Studies 7(1): 17-30. 
Rowthorn, Robert and Ken Coutts (2004) 'De-Industrialization and the Balance of Payments in Advanced Economies', UNCTAD/OSG/DP/2004/4.

Samuelson, Paul and William D. Nordhaus (2005) Economics, New York: McGraw-Hill.

Scruggs, Lyle (2007) 'Welfare State Generosity across Space and Time', in Jochen Clausen and Nico Siegel, eds, Investigating Welfare State Change: The Dependent Variable Problem in Comparative Analysis, 133-65, Northampton, Mass.: Edward Elgar.

Scruggs, Lyle, Detlef Jahn and Kati Kuitto (2014) 'Comparative Welfare Entitlements Dataset 2. Version 2014-03', University of Connecticut and University of Greifswald.

Seabrooke, Leonard and Duncan Wigan (2015) 'Powering Ideas through Expertise: Professionals in Global Tax Battles', Journal of European Public Policy 23(3): 357-74.

Shoch, James (2000) 'Contesting Globalization: Organized Labor, NAFTA, and the 1997 and 1998 Fast-Track Fights', Politics and Society 28(1): 119-50.

Steinberg, Mark (1998) 'Tilting the Frame: Considerations on Collective Action Framing from a Discursive Turn', Theory and Society 27(6): 845-72.

Stewart, Eugene (1971) 'Import Competition and Government Relief', in United States International Economic Policy in an Interdependent World. Papers Submitted to the Commission on International Trade and Investment Policy and Published in Conjunction with the Commission's Report to the President, Washington: US Government Printing Office.

Stolper, Wolfgang and Paul Samuelson (1941) 'Protection and Real Wages', Review of Economic Studies 9(1): 58-73.

Watson, Matthew (2014) Uneconomic Economics and the Crisis of the Modern World, New York: Palgrave MacMillan.

Weber, Max (1905/2010) The Protestant Ethic and the Spirit of Capitalism, Oxford: Oxford University Press. 
Widmaier, Wesley (2016) 'The power of economic ideas - through, over and in - political time: the construction, conversion and crisis of the neoliberal order in the US and UK', Journal of European Public Policy 23(3): 338-56.

Widmaier, Wesley W. (2004) "The Social Construction of the "Impossible Trinity": The Intersubjective Bases of Monetary Cooperation', International Studies Quarterly 48(2): $433-53$.

\section{About the Author}

Juan Díez Medrano has been a Professor of Sociology in the Department of Social Sciences at the Universidad Carlos III de Madrid since 2010. He is a former Professor of Sociology at the University of California, San Diego (1989-2003), Jacobs University Bremen (2002-2004) and the University of Barcelona (2003-2010). He is the author of publications related to nationalism, ethnic conflict, and European integration, the latter with an emphasis on public opinion and social transformations. He has published widely in well-known journals, such as the American Sociological Review, Social Forces, Ethnic and Racial Studies, Theory and Society, Review of International Political Economy, Population, Space, and Place, and Comparative European Politics. He has also published the monographs Divided Nations (Cornell University Press, 1995) and Framing Europe (Princeton University Press, 2003). Additionally, he regularly presents papers at the American Sociological Association's and Council for European Studies' annual conferences. He has been involved in FP6 and FP7 research projects since the early 2000s and has coordinated projects sponsored by the ESF and funded by the Spanish National Funding Agency. Prof Díez Medrano is a member of the Scientific Advisory Board of the Wissenschaftszentrum Berlin für Sozialforschung and the Juan March Institute for the Social Sciences. He was also the Chair of the Council for European Studies between 2013 and 2015. 


\section{Tables and Figures}

Table 1. FTAs and similar trade liberalisation treaties or framework agreements for trade liberalisation - USA and EU (1985-2012)

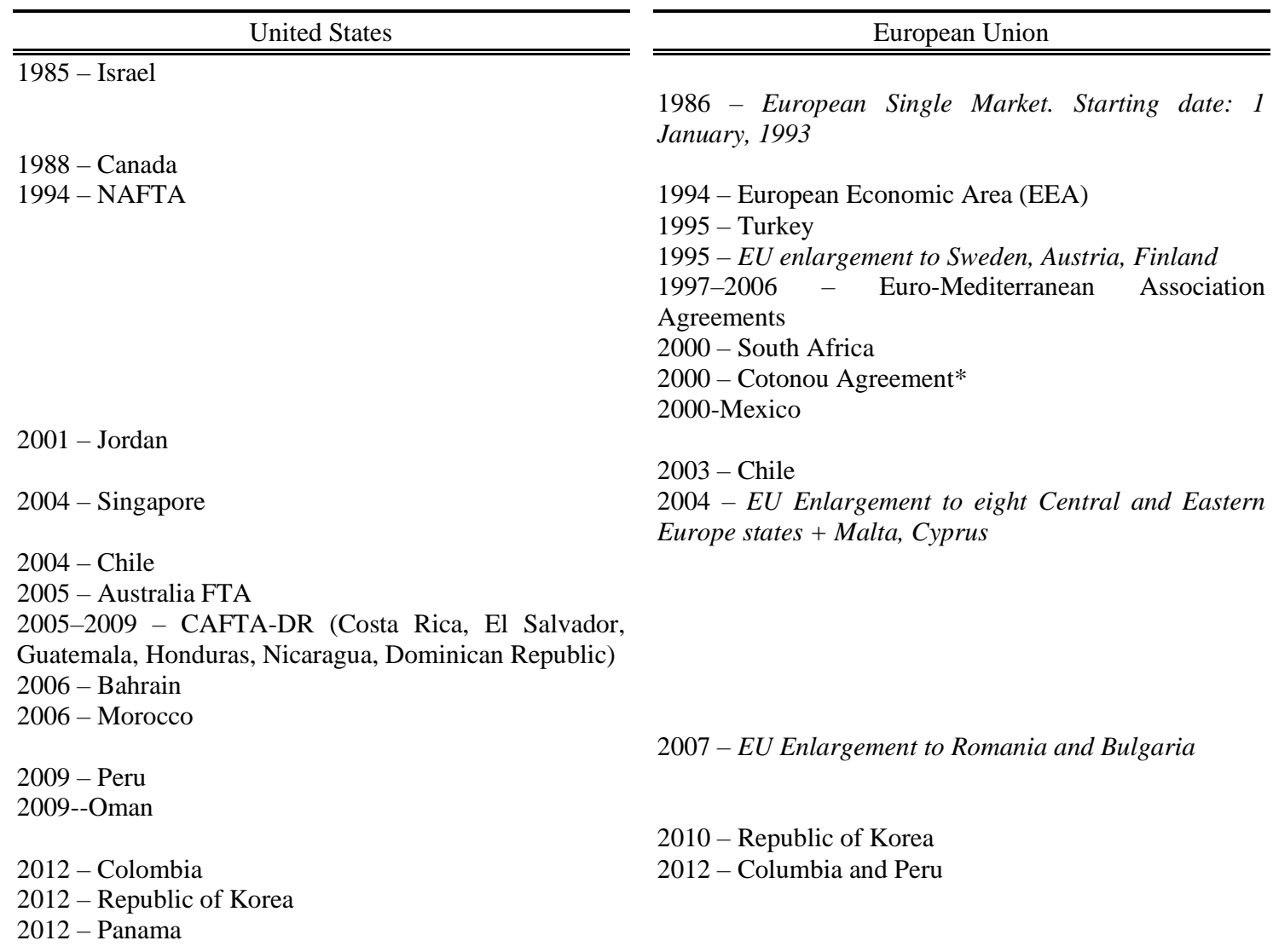

* A framework for the development of FTAs. The only economic partnership agreement finalised thus has been with West Africa (2014). It is pending ratification. 
Table 2. Statements and evaluations concerning the role and impact of foreign trade (AFL-CIO and TUC)*

\begin{tabular}{|c|c|}
\hline $\begin{array}{c}\text { United States } \\
\text { (AFL-CIO) } \\
\text { (44 statements/evaluations) }\end{array}$ & $\begin{array}{c}\text { United Kingdom } \\
(\text { TUC }) \\
\text { (47 statements/evaluations })\end{array}$ \\
\hline \multicolumn{2}{|c|}{ Role of foreign trade in the economy } \\
\hline & $\begin{array}{l}\text { Foreign trade plays a major role in the national } \\
\text { economy }\end{array}$ \\
\hline \multicolumn{2}{|c|}{ Negative impact } \\
\hline \multicolumn{2}{|c|}{ Bad for national economy } \\
\hline \multicolumn{2}{|c|}{ Excessive volume of imports, trade deficits } \\
\hline \multicolumn{2}{|c|}{ Loss of jobs } \\
\hline $\begin{array}{r}\text { Weaker and inad } \\
\text { Rights at }\end{array}$ & $\begin{array}{l}\text { quate protection of workers' } \\
\text { working conditions }\end{array}$ \\
\hline \multicolumn{2}{|c|}{ Detrimental to low income families, workers, farmers, or communities } \\
\hline \multicolumn{2}{|c|}{ Relocations } \\
\hline $\begin{array}{l}\text { Decline in real wages } \\
\text { Decline in standards of living } \\
\text { Obstacles to unionisation } \\
\text { Endangered population health due to } \\
\text { imports } \\
\text { Income inequality } \\
\text { Unprotected consumers } \\
\text { Unprotected public services }\end{array}$ & \\
\hline \multicolumn{2}{|c|}{ Positive impact } \\
\hline Goo & tional economy \\
\hline
\end{tabular}




\begin{tabular}{|l|l|}
\hline & Job creation \\
Good for some industrial sectors \\
Incentives to produce better goods and services
\end{tabular}

*See Primary Sources

(Tables with quotes corresponding to the different categories available upon request) 
Table 3. Statements and evaluations concerning the impact of foreign trade agreements (AFL-CIO and TUC)*

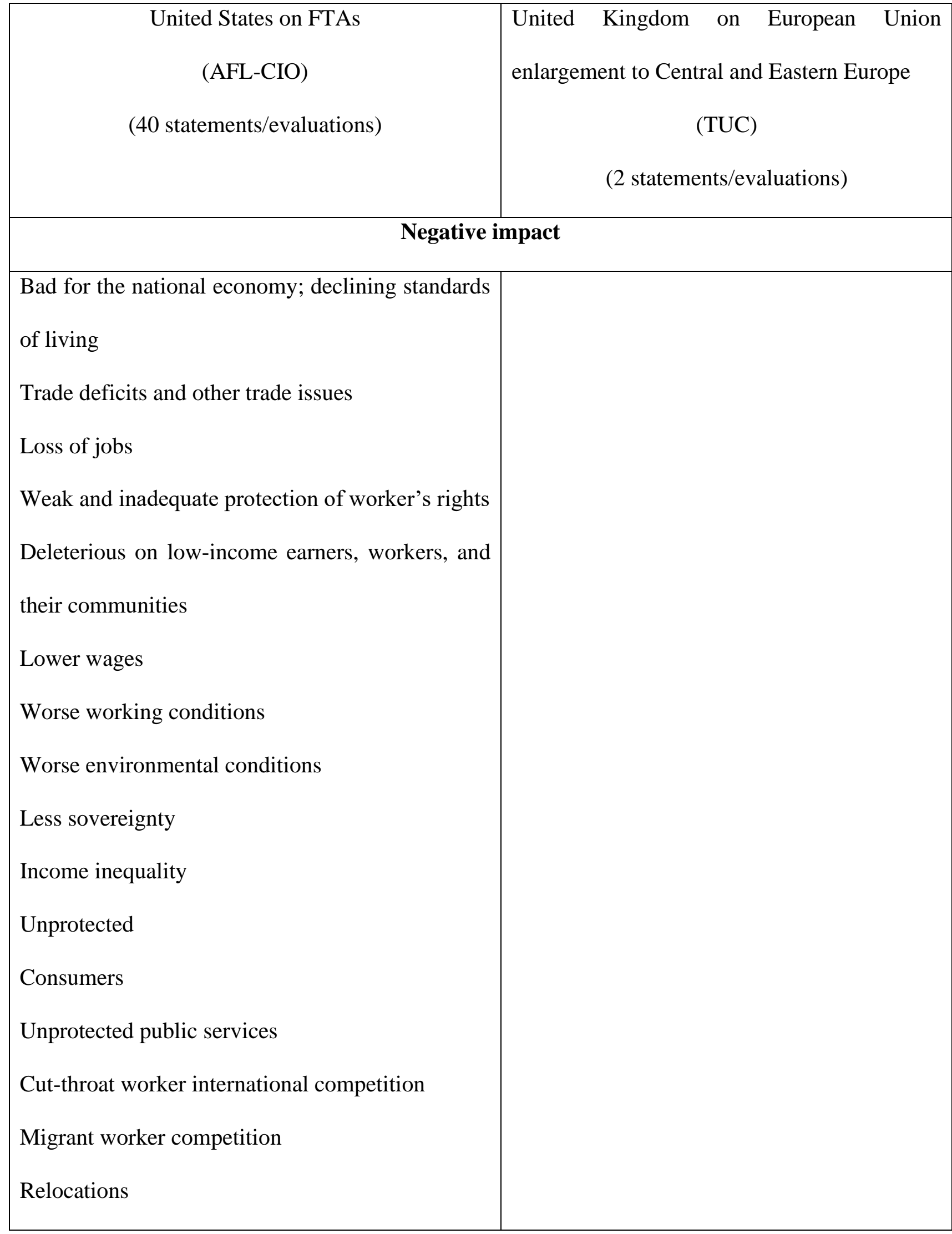




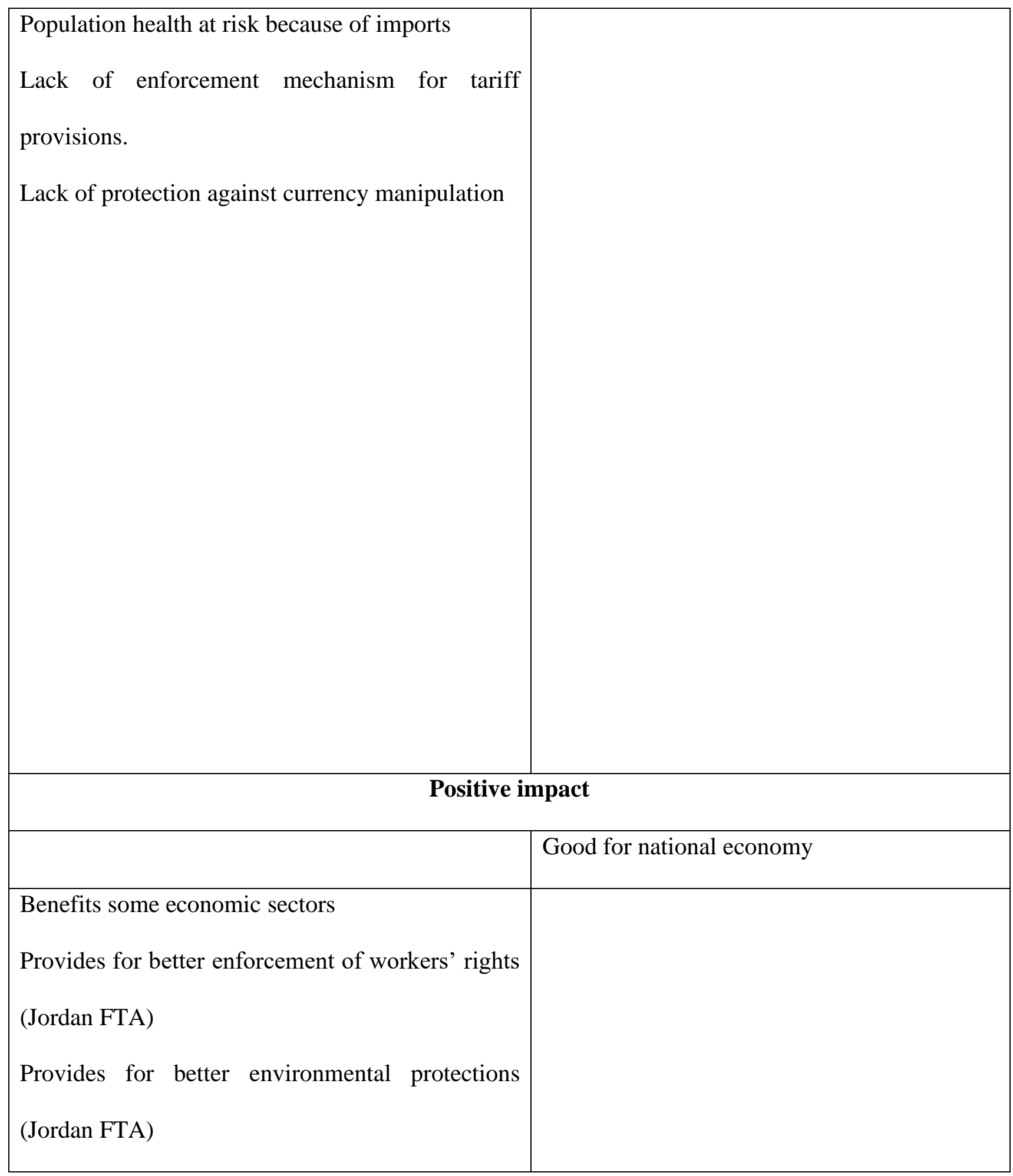

*See Primary Sources 